\title{
Preparedness of Teachers to Maintain Discipline in the Absence of Corporal Punishment in Bondo District Kenya
}

\author{
Dr. Jack O. Ajowi \\ School of Education \\ Jaramogi Oginga Odinga \\ University of Science and Technology \\ Box 210 - 40601, Bondo, Kenya. \\ Corresponding author: jackajowi@yahoo.com \\ Ms. Christine Juma Omboto \\ Master (Med. Administration) Student \\ Maseno University \\ P. O. Box 34 Kisumu
}

Doi:10.5901/jesr.2013.v3n2p123

\section{Abstract:}

Discipline of students is critical to educators, parents, and the society as a whole. Secondary schools in Kenya have experienced problems of student discipline for along time. In the year 2001 alone, after the government had banned the use of corporal punishment in schools, 253 schools all over the country went on strike. Most people attributed the trend of strikes in schools to the ban on corporal punishment. While the schools all over the country were portraying a trend of violence, those in Bondo district in Nyanza province appeared incredibly calm with only one case of student strike reported in five years. The study set to find out how the teacher managed student discipline in public secondary schools in Bondo district. The study used survey research design and targeted 40 public secondary schools. Stratified and simple random sampling techniques were used to select a sample of 3 boys' schools, 2 girls' and 8 mixed secondary schools for study. A total of 13 secondary schools were sampled. Saturated sampling was used to select all the 13 head teachers, 13 deputy head teachers and 13 heads of guidance and counseling. 26 classroom teachers were selected by simple random and convenient sampling technique, while the students were stratified per class and then 780 of them were selected based on simple random sampling from forms 2, 3 and 4 classes. Form 1 class did not participate in the study because they had just reported in school. Questionnaires, in-depth interview schedules and school documents on discipline were used to collect data. The face and contents of the instruments were validated by experts in the department of educational management in Maseno University and tried out in 2 secondary schools twice at intervals of two weeks in order to determine their ability to generate accurate data. Data were mainly analyzed using basic descriptive statistics like frequencies and mean. Some data from interview schedules were organized into themes and reported verbatim as they emerged from the field.

Keywords: Teacher, Bondo District, Management, Student Discipline, Public Secondary Schools, Kenya.

\section{Introduction}

Discipline of students is critical for the proper running of a school. Parents, as first educators start their children on the path of discipline and the teacher later continues it at school. Chambers (1983) observes that while order is necessary for discipline to prevail, order is based on external control and fear while discipline is internal and comes from the individual because they understand the need for it.

Secondary schools in Kenya have experienced problems of discipline with their students since 1971 when the first case of violent student strike was reported. The government thought that the strike occurred because schools did not have a strong internal mechanism of dealing with student disciplinary problems. It therefore introduced corporal punishment in schools in 1972 (Education Act Cap 211, 1980). The good intentions with 
which the government introduced corporal punishment in schools and which Griffin's recommendations were based on waned off and the teacher transformed the cane into an instrument of terror and brutality. Kamuyu (2001) observes that pupils lost their lives as the teacher brutally applied the cane on them and others suffered irreparable psychological damage. The government responded to save the child from teacher tyranny by banning the use of corporal punishment in schools under legal notice 56/2001(Republic of Kenya, 2001).

The government, through MOEST suggested that guidance and counseling services in schools should be strengthened to provide a new way of managing student discipline. However, the structures for providing guidance and counseling in schools are still so weak that it is doubtful whether they will adequately fill the gap left as a result of the ban on corporal punishment (ROK, 1988; RoK, 1999, RoK, 2001 and RoK, 2005). Though strengthening of guidance and counseling services in schools would provide the most lasting internal mechanism for managing student discipline. By banning corporal punishment the government expected to restore calm in schools but apparently violence has continued to reign in schools. However, secondary schools in Bondo district appeared to have been spared the violence and seemed to enjoy relative calm. The study set to find out how the teacher managed student discipline in secondary schools in Bondo district and whether it was associated with the calmness in the schools.

The ban on corporal punishment in schools in 2001 coincided with some strikes and student riots. Some 253 schools in the entire republic went on strike in the same year. This however excluded tertiary institutions, which also went on strike. Interestingly, primary schools also joined the fray of school strikes. Nyanza Province recorded seven cases of schools that went on strike (Republic of Kenya, 2001). Out of the seven cases, Bondo District had one case of strike in that year. Up to the time of research in early 2004 no secondary school had recorded any riot in the district. The calmness of schools in the district however might not reflect the true state of discipline of the students in the schools. It could not be immediately discerned whether the calmness was a result of teacher participation in managing student discipline or was as a result of other factors. This study, therefore, set to establish how the teacher managed discipline of the students in the public secondary schools in Bondo District.

\section{Research Questions}

The following questions guided the study:

1. What are the student disciplinary problems found in schools?

2. What is the policy of the MOEST on student discipline?

3. Are teachers aware of MOEST policy on school discipline?

4. How prepared is the teacher in handling student disciplinary problems?

5. What methods the teacher used to handle student disciplinary problems?

6. What difficulties does the teacher face in managing student disciplinary problems?

7. What support does the teacher require to manage student discipline better?

\section{Research Methodology}

The study used descriptive survey design. Fraenkel \& Wallen (1993) define survey as that method that involves asking a large group of people questions about a particular issue. Information is obtained from a sample rather than the entire population at one point in time, which may range from one day to a few weeks. It employed descriptive survey to establish opinions, attitudes and knowledge about the teacher in the management of student discipline. Any research undertaking involves lots of cost implications hence; descriptive survey design was deliberately selected for the study because it allows for quick data collection at a comparatively cheap cost (Grinnell, 1993).

The study was conducted in Bondo District in the Republic of Kenya. Bondo is one of the twelve districts that make up Nyanza Province in the western Kenya region. It was carved out of Siaya District in May 1998. The district has a geographical area of $1,972 \mathrm{~km}^{2}$ of which $972 \mathrm{~km}^{2}$ is land while $1000 \mathrm{~km}^{2}$ is covered with water. It lies between Latitude $0^{\circ}$ to $30^{\circ}$ South of the Equator and Longitude $30^{\circ}$ to $34^{\circ}$ East. The study focused on a population of forty secondary schools in Bondo District: eight boys', seven girls' and, twenty-five mixed 
secondary schools. The district had more mixed day schools than single sex boarding schools. That could be attributed to the high poverty levels in the district, which made the boarding fees too high for most parents to afford. The total student population in all the secondary schools was 8319 out of whom, 5044 were boys while 3275 were girls and 360 teachers (District Education Office, Bondo, 2004). Cohen \& Manion (1994) observe that factors of expense, time and accessibility always make it not possible to obtain information from the whole target population. Researchers therefore endeavour to collect information from a smaller population in such a way that the knowledge gained is representative of the total population under study.

The researcher used simple random sampling technique to sample the respondents. Simple random sampling is a procedure that is used to reduce chance variation between a sample and the population it represents (Grinnell, 1993 \& Gall et all, 1996). A third (30\%) of the schools in each stratum were selected. Each school was given a code number in its strata. The code numbers were then written down on different pieces of paper and put in three different containers that were marked according to the strata of schools. From each container, the number of papers representing a third of schools in each strata were picked at random. That yielded three boys' schools, two girls' schools and eight mixed schools.

Fraenkel \& Wallen (1993) observe that survey research has four basic ways of collecting data, namely: administering the instrument 'live' to a group; by mail; by telephone and by face-to-face interview. This study used direct method where the instruments were administered live to respondents. The reason was that the method yields high response rate at a low cost and enables the researcher to explain and answer questions from the respondents. Face-to-face interview was also used because it helps to enlist cooperation of respondents and to establish rapport with them. Borg et all (1993) observe that questionnaire are often used to collect basic descriptive information from a large sample while interviews are used to follow up questionnaire responses in depth with a smaller sample. The researcher collected data using questionnaires and in-depth interview schedules. School records on student discipline like the punishment books also supplied complementary data. Questionnaires contained both open-ended and closed-ended items. Fraenkel \& Wallen (1993) observe that closed-ended questions are used in research because they are easy to use, score and code for analysis while open-ended questions allow for individualized response.

The study used four types of questionnaires, namely: Head teacher Questionnaire (HQ), Heads of Guidance and Counselling Questionnaire (G\&CQ), Classroom Teacher Questionnaire (CTQ) and Student Questionnaire (SQ). Cohen \& Manion (1994) observe that pupils and student teachers are relatively easy to survey while gypsy children and head teachers are more elusive. The researcher conducted in-depth interviews with the deputy head teachers and the classroom teachers. That was because classroom teachers handled disciplinary cases that arose in their classes before they forwarded them to either the heads of guidance and counselling or the deputy head teacher. The classroom teachers in most boarding schools were also in charge of houses where the students slept. Their position enabled them to discuss effectively the student disciplinary problems that arose from the classes as well as houses.

The deputy head teacher, on the other hand, was the head of discipline and chairman of the disciplinary committee in the school. Consequently, the committee made recommendations on all major disciplinary issues in schools. The deputy head teacher also received information on all disciplinary issues in the school and kept them in records. All those facts, taken together, made deputy head teachers in schools pertinent sources of useful information for the study. The researcher perused through the available student disciplinary records like the punishment book in order to shed more light on the nature of disciplinary problems faced and methods used by the teacher to handle them. The deputy head teachers kept those records. The teacher on duty (ToD) also kept some records of disciplinary management on weekly basis. The records provided

In order to ascertain content and face validity of the questionnaires and in-depth interview schedules they were presented to lecturers in the department of Educational Management at Maseno University who are authorities in the area for scrutiny and advice. The contents and impressions of the instruments were improved based on the judges' advice and comments. The questionnaire and in-depth interview items were then constructed in a way that they related to each research question. That ensured that all research questions were covered.

To ensure reliability of the instruments, the researcher conducted a pilot study in two schools before the actual study. Those schools were not included in the main study. Questionnaires were administered to the same respondents after an interval of two weeks. The main purpose of the pilot study was to help in clarifying 
questions, to check on the level of language used and to identify any other areas of difficulty, which could impede effective response. The researcher asked the respondents to mark out the unclear questions and make suggestions for improvements. Test- retest helps to compare the results of the two experiments and to devise ways of sealing the gap. The suggestions obtained from respondents were used to improve on and to clear the vague and ambiguous questions. Ultimately, the researcher had a polished questionnaire that collected information that was relevant to the study.

Basic descriptive statistics was used mostly to analyze information generated by the questionnaire, interview schedules and the attitude scales. The units of analysis were the students and the teachers. Data for analysis were obtained from responses to questionnaires, in-depth interviews and school records on discipline. Responses to the closed-ended and open-ended questionnaire items were tallied in summary in sheets and converted into percentages.

Information from in-depth interviews was organized in themes, categories and sub-categories that emerged and analyzed qualitatively using direct quotations and verbatim reports from the deputy head teachers and classroom teachers in order to capture the true state of student discipline in schools. Information from the school records on discipline was used to complement and to cross check data collected using the main instruments. They were analyzed qualitatively through verbatim reports based on themes, categories and subcategories and, quantitatively using basic descriptive statistics, like frequencies and percentages.

\section{Results}

\section{Policy of MOEST on School Discipline}

In order to evaluate the role of the teacher in managing student discipline in schools, it was necessary to find out whether the MOEST had any policy guidelines on school discipline and if the teachers were aware of the policy. All the $11(100 \%)$ head teachers and $13(100 \%)$ deputy head teachers who responded agreed that the MOEST had a policy guideline on school discipline. They also indicated that the policy guidelines were contained in the Education Act Cap.211 (1980), Manual for Heads of Secondary schools of (1987) and the Kenya Gazette Legal Notice 56/2001 of March 2001 and the Policy Framework for Guidance and Counselling in School produced in April 2002.

\section{Student Disciplinary Problems in Boys' schools}

When asked what disciplinary problems were experienced with the students in schools, the respondents gave diverse views, which have been presented in Table 1. 
Table 1: Student Disciplinary Problems

\begin{tabular}{|c|c|c|c|c|c|}
\hline Student & Students & $\mathbf{C T}$ & $\mathbf{G} \& \mathbf{C T}$ & DH/T & Mean \\
\hline Disciplinary & $\mathbf{n}=\mathbf{2 3 0}$ & $n=6$ & $\mathbf{n}=\mathbf{3}$ & $\mathbf{n}=\mathbf{3}$ & Percentage \\
\hline Problems & $\mathbf{f}(\%)$ & $\mathbf{f}(\%)$ & f $(\%)$ & $\mathbf{f}(\%)$ & $(\%)$ \\
\hline Noisemaking & $200(87)$ & $6(100)$ & $3(100)$ & $3(100)$ & 97 \\
\hline Fighting & $154(67)$ & $5(83)$ & $3(100)$ & $3(100)$ & 88 \\
\hline Sneaking out school & $76(33)$ & $5(83)$ & $3(100)$ & $3(100)$ & 79 \\
\hline Incomplete homework & $92(40)$ & $6(100)$ & $3(100)$ & $2(67)$ & 77 \\
\hline Defiance of authority & $138(60)$ & $5(83)$ & $3(100)$ & $2(67)$ & 76 \\
\hline Cheating in Internal Exams & $7(03)$ & $6(100)$ & $2(67)$ & $3(100)$ & 68 \\
\hline Bullying & $0(0)$ & $6(100)$ & $3(100)$ & $2(67)$ & 67 \\
\hline Drug Use & $30(13)$ & $5(83)$ & $2(67)$ & $3(100)$ & 66 \\
\hline Arson & $76(33)$ & $2(32)$ & $1(32)$ & $1(33)$ & 33 \\
\hline Strike & $36(20)$ & $2(32)$ & $1(33)$ & $1(33)$ & 30 \\
\hline \multicolumn{6}{|l|}{ Other Disciplinary Problems } \\
\hline Truancy & $60(33)$ & $4(67)$ & $2(67)$ & $2(67)$ & 59 \\
\hline Theft & $46(26)$ & $4(67)$ & $2(67)$ & $2(67)$ & 57 \\
\hline Failure to do Manual work & $60(20)$ & $5(83)$ & $2(67)$ & & 43 \\
\hline Sleeping during class time & $76(20)$ & $5(83)$ & $2(67)$ & 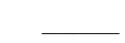 & 43 \\
\hline Mother Tongue Speaking & $46(26)$ & $4(67)$ & $2(67)$ & & 40 \\
\hline
\end{tabular}

From Table 1, it emerges, that noisemaking, fighting, incomplete homework, sneaking and defiance led in the list of student disciplinary problems in Boys' schools. Interviews conducted with the deputy head teachers and classroom teachers revealed that, fighting and noisemaking were more conspicuous amongst form one students who had not mastered the school rules and regulations. The class teachers and deputy head teachers observed that noisemaking was common among the lazy and less industrious students and also some brilliant students with short concentration span. Incomplete homework was a serious problem as indicated in the responses of 6 (100\%) class teachers, 2 (67\%) deputy head teachers and 3 (100\%) heads of guidance and counseling. Interviews with class teachers and deputy head teachers revealed that incomplete homework was more conspicuous amongst form two and three students and especially in Mathematics and Kiswahili. They further indicated that most form one students did homework out of fear of the consequences, while form four students were more focused on passing their final examinations and regarded completing homework as a gateway. On the other hand only 92 (40\%) students regarded failure to complete homework as a disciplinary problem. This may reveal that either the students were not serious with their class work or failure to complete homework was not included in the school rules and regulations and therefore they did not regard it an indicator of indiscipline.

The study further found out that perverted sexual relationship like homosexuality was not a problem in the schools. Only one school reported an isolated case that had occurred three years ago. The study also found out that students sneaked out of school and 5 (83\%) class teachers, 3 (100\%) deputy head teachers and 3 (100\%) heads of guidance and counseling considered it a serious disciplinary problem while only 76 (33\%) students thought it was an act of indiscipline. The class teachers and deputy head teachers clarified in the interviews that those who sneaked out of school were mostly students from towns who were forced to join the schools by their parents or guardians against their wishes. Those students sneaked out of school as a way of protesting such decisions. One hundred and thirty eight (60\%) students, 5 (83\%) class teachers, $2(67 \%)$ deputy head teachers and $3(100 \%)$ heads of guidance and counselling indicated that defiance of authority was common among 
students. However, it mostly affected the prefects who then reported such defiant cases to the ToD or the deputy head teacher. Teachers seemed to experience only mild cases of rudeness from students. As regards bullying $2(67 \%)$ deputy head teachers, $6(100 \%)$ class teachers and $3(100 \%)$ heads of guidance and counseling indicated that it was a disciplinary problem but none $(0 \%)$ of the students saw it as a disciplinary problem. On drug use 5 (83\%) class teachers, $3(100 \%)$ deputy head teachers and $2(67 \%)$ heads of guidance and counselling indicated that students used it. Interviews conducted with the $\mathrm{C} / \mathrm{Ts}$ and $\mathrm{DH} / \mathrm{Ts}$ revealed that most of the student drug users originated from towns and consumed them in tablet form and alcohol mixed in juice. Students from poor economic backgrounds on the other hand used smoked drugs like cigarettes and bhang, which they obtained cheaply. Given the high poverty levels in Bondo District and the government policy of admission of $85 \%$ of students from the home district, it appeared that majority of the students in secondary schools in the district came from low socio-economic backgrounds.

While $6(100 \%)$ C/Ts, $3(100 \%) \mathrm{DH} / \mathrm{Ts}$ and $2(67 \%)$ heads of G\&C indicated that cheating in internal examinations was common among students; only7 (3\%) of the students thought it was a disciplinary problem. The $\mathrm{C} / \mathrm{Ts}$ and $\mathrm{DH} / \mathrm{Ts}$ further observed in the interviews that cheating in exams was common with weak students who feared elimination or repetition if they failed. Arson case ranked low in the list. In the past two years, two schools had suffered from arson and only one of them was part of the study. Therefore 76 (33\%) students, 2 (32\%) C/Ts, 1 (33\%) DH/Ts and 1 (32\%) head of G\&C indicated that their schools were affected by arson. Other disciplinary problems, which emerged, included speaking mother tongue, failure to perform manual work, theft, truancy and sleeping during class time.

However much as 4 (67\%) C/Ts, 2 (67\%) DH/Ts and 2 (67\%) heads of G\&C indicated that they were serious disciplinary problems; only 70 (30\%) students regarded them seriously. That could imply that either they were not included in the school rules or the students did not regard them as serious disciplinary offences. A look at the list of school rules of two schools confirmed that truancy and sleeping during class time were not included in the list of disciplinary offences in the schools. Schools should explicitly write and pin on student notice boards the list of school rules for the benefit of students. From the study it emerged that boys' schools in Bondo district had disciplinary problems.

\section{Methods of Managing Discipline Used in Schools}

The study set to establish the methods used by teachers to manage student discipline in boys' schools. They were presented in Table 5 in order of intensity and frequency of their use in boys' schools. 
Table 2: Methods of Managing Discipline in Schools

\begin{tabular}{|c|c|c|c|c|c|}
\hline Method & Students & $\mathrm{C} / \mathrm{T}$ & G\&CT & DH/T & Mean \\
\hline \multirow[t]{2}{*}{ Used } & $\mathbf{n}=\mathbf{2 3 0}$ & $n=6$ & $n=3$ & $n=3$ & Percentage \\
\hline & $\mathrm{f}(\%)$ & $f(\%)$ & $f(\%)$ & $f(\%)$ & (\%) \\
\hline Manual Labour & $223(97)$ & $6(100)$ & $3(100)$ & $3(100)$ & 99 \\
\hline Guidance and counseling & $214(93)$ & $6(100)$ & $3(100)$ & $3(100)$ & 98 \\
\hline Suspension & $191(83)$ & $6(100)$ & $3(100)$ & $3(100)$ & 96 \\
\hline \multicolumn{6}{|l|}{ Withdrawal from favourite } \\
\hline activity & $108(47)$ & $4(67)$ & $3(100)$ & $3(100)$ & 79 \\
\hline \multicolumn{6}{|c|}{ Physical Punishment e.g. kneeling } \\
\hline knocking etc & $198(86)$ & $4(67)$ & $0(0)$ & $3(100)$ & 63 \\
\hline Imposing Fine & $23(10)$ & $4(67)$ & $2(67)$ & $3(100)$ & 61 \\
\hline Exclusion & $30(13)$ & $4(67)$ & $2(67)$ & $2(67)$ & 54 \\
\hline Put students out of clalss & $145(63)$ & $5(83)$ & $0(0)$ & $2(67)$ & 53 \\
\hline Corporal punishment & $30(13)$ & $0(0)$ & $1(33)$ & $3(100)$ & 37 \\
\hline
\end{tabular}

From Table 2, it emerged that manual labour, guidance and counselling and suspension ranked highest in the list of methods used to discipline errant students in boys' schools. From interviews C/Ts and DH/Ts clarified that manual forms of punishments included slashing, digging, uprooting stumps, weeding, trimming the fence, sweeping the paths, mopping and many more. Each one of them could be recommended at the discretion of the teacher depending on the offence. All C/Ts and heads of G\&C appeared to use guidance and counseling whenever the $\mathrm{DH} / \mathrm{Ts}$ and/or $\mathrm{H} / \mathrm{Ts}$ referred any disciplinary case to them. All the categories of teacher respondents and 191 (83\%) students indicated that suspension was used on students. In fact, 2 (67\%) DH/Ts observed in the interviews that suspension of students was safer than using most of the other disciplinary methods which were illegal. All heads of $\mathrm{G} \& \mathrm{C}, \mathrm{DH} / \mathrm{Ts}$ and $4(67 \%) \mathrm{C} / \mathrm{Ts}$ indicated that withdrawal of students from their favourite activities was also used often as a disciplinary strategy. One hundred and ninety eight (86\%) students, $4(67 \%) \mathrm{C} / \mathrm{Ts}$, and $3(100 \%) \mathrm{DH} / \mathrm{Ts}$ indicated that physical punishment (like, pinching, kneeling and knocking) and putting students out during class time were popular with teachers. However none of the heads of G\&C supported the use of those methods. All DH/Ts and 1 (33\%) head of G\&C used corporal punishment on the students but none of the class teachers used it at all.

Despite the ban on corporal punishment it was still widely used and favoured by the deputy head teachers with the support of the $\mathrm{H} / \mathrm{Ts}$. When asked whether the ban on corporal punishment had compromised the ability of the teacher to control the students, $11(100 \%)$ of the head teachers strongly disagreed and in fact, maintained that the teachers' control was intact. It seemed that the ban on corporal punishment was in books of law but in practice in schools it appeared intact. A deputy head teacher remarked on the same issue "you might not see a cane in this office right now but, when its use becomes necessary, it will always appear". A student also observed that, "a school where there is no caning has never done well, cannot do well and will never do well" and another one said that "manual labour is just a way of satisfying my wish when I feel tired in class, I can simply make noise so that I go out. Likewise, suspension is just a chit for going out but caning is what we fear most". The head teacher is responsible for setting and maintaining the tone and all-round standards in the 
school and his/her position will determine what the teachers do (Republic of Kenya, 1987). However, the entrenched and hardened position assumed by the head teachers and their principal assistants on the use of the cane seemed to make it difficult for the MOEST ban on corporal punishment to succeed in schools. In fact it requires the intervention of parents or quality assurance and standards officers from the MOEST to deal with teachers who violate the law.

However, no C/T seemed to favour the use of corporal punishment. During the interview one classroom teacher expressed candidly that managing student discipline with corporal punishment only forced the students to comply in school but it did not teach them true self discipline and that when those students joined colleges, they displayed the worst habits of drunkenness and led demonstrations and riots. Apparently, most students were also not enthusiastic about the use of corporal punishment by teachers. When asked whether the government should restore corporal punishment in schools to enable the teacher handle student discipline better 476 (61\%) students strongly disagreed. A student captured that position more explicitly in the following observation "caning merely inflicts physical pain on the culprit but does not make him aware of the adverse consequences of bad behaviour, or in discipline". Having established the disciplinary methods used in boys' schools, the next step was to find out the disciplinary methods used in girls' schools.

\subsection{Preparedness of the Teacher in Managing Student Discipline}

The study set to find out how prepared the teacher was in managing student discipline in secondary schools. This was important because the preparedness of the teacher would bring out the areas where the teacher felt inadequate, hence, guide in making recommendations on the strategies to help the teacher manage student discipline in a better way. Table 12 shows the responses to the issue of teacher preparedness to manage student discipline in schools.

Table 3: Teacher Preparedness in Managing Student Discipline

\begin{tabular}{lcccccc}
\hline Level & $\begin{array}{l}\text { Students } \\
\mathbf{n = 7 8 0}\end{array}$ & $\begin{array}{l}\mathbf{C} / \mathbf{T} \\
\mathbf{n = 2 6}\end{array}$ & $\begin{array}{c}\mathbf{G} \& \mathbf{C} \\
\mathbf{n}=\mathbf{1 3}\end{array}$ & $\begin{array}{l}\mathbf{D H} / \mathbf{T} \\
\mathbf{n = 1 3}\end{array}$ & $\begin{array}{c}\mathbf{H} / \mathbf{T} \\
\mathbf{n}=\mathbf{1 3}\end{array}$ & $\begin{array}{c}\text { Mean } \\
\text { Percentage }\end{array}$ \\
& $\mathbf{F}(\%)$ & $\mathbf{f}(\%)$ & $\mathbf{f}(\%)$ & $\mathbf{f}(\%)$ & $\mathbf{f}(\%)$ & $\mathbf{( \% )}$ \\
\hline Agreed & $86(11)$ & $13(48)$ & $3(23)$ & $4(31)$ & $0(0)$ & 23 \\
Disagreed & $616(79)$ & $13(48)$ & $10(77)$ & $9(69)$ & $11(85)$ & 72 \\
Undecided & $70(9)$ & $1(4)$ & $0(0)$ & $0(0)$ & $0(0)$ & 3 \\
Non Response & $8(1)$ & $0(0)$ & $0(0)$ & $0(0)$ & $2(15)$ & 3 \\
\hline
\end{tabular}

From Table 3, 616 (79\%) students, 10 (77\%) heads of G\&C, 9 (69\%) DH/Ts, 11 (85\%) H/Ts and 13 (48\%) C/Ts disagreed that the teacher was adequately prepared to manage student discipline. Teacher preparedness focused on how confident the teacher was in managing student discipline in schools given the skills and knowledge s/he acquired from pre-service and in-service training.

\subsection{Difficulties the Teacher Experiences in Managing Student Discipline}

When asked what difficulties the teachers experienced while managing student discipline in schools, the respondents identified a number of difficulties that the teacher faced and areas where the teacher was weak and hence needed support. 


\section{a) Views of Head teachers}

All the 11 head teachers observed that some teachers administered punishments to students with anger and that made them suggest impossible punishments before exploring the reasons for student misbehaviour. Such disciplinary measures were resented by students hence were counterproductive. Some 8 (80\%) head teachers complained that sponsors insisted that a person of their faith or clan must head their schools and that interfered with the stability of school management. This finding agrees with observations and findings of various commission reports on education that a number of conflicts prevailed between sponsor and heads of institutions (Republic of Kenya, 2001).

In some schools $4(30 \%)$ head teachers indicated that they had a conflict with school BOG over tenders and the head teachers were threatened with removal or transfer. That made the unwanted head teachers complacent hence neglected student discipline. Eleven (100\%) head teachers also observed that the district and provincial education offices interfered with the management of student discipline in schools. That was because they sometimes directed head teachers to admit students expelled from other schools due to indiscipline. That lot of students with disciplinary problems had a bad influence on the rest of the students. The same office ordered the re-admission of students recommended for either expulsion or suspension. That compromised the ability of the head teacher to control the students hence, undermining the school discipline. That finding reinforced the observation that inefficient management of education in the developing countries is due in part to political interference in decision-making (World Bank, 1980; UNESCO, 1996 and Republic of Kenya, 1999).

\section{b) Views of $D H / T s$, Heads of G\&C and $C / T S$}

All the 13 (100\%) deputy head teachers, 13 (100\%) heads of G\&C and 26 (100\%) C/Ts observed that the policy of the MOEST on punishment in schools was not clear. They indicated that the ban on corporal punishment was communicated to schools in a circular but the MOEST had not clarified the status of guidance and counselling in schools and how the teachers were to behave with regard to Children and Young persons Act. That uncertainty made management of student discipline in schools difficult. Hence, the teachers were either referring students with disciplinary problems to the heads of guidance and counselling, the deputy head teachers or putting them out of class on manual work.

All 26-classroom teachers indicated that they had a problem of balancing the roles of guidance and counselling and punishment in the classroom situation. They observed that the roles were conflicting, hence, should be separated. They also observed that they lacked adequate skills to manage the complex classroom disciplinary problems. One classroom teacher remarked "we punish students for wrong doing and offer guidance counseling when punishment fails, but how do we detect that punishment has failed when we hardly go for seminars on guidance and counselling?" Ideally guidance and counseling should be for all levels of learning and classroom teachers require it most to solve complex disciplinary problems in class but it is a pity that they lack such skills. The fact that teachers hardly go for in-service training in guidance counseling may mean that their pre-service training is deemed adequate to make them competent teachers. However, the study findings revealed that pre-service training of teachers did not adequately prepare them for the future professional tasks especially student discipline management.

Eighteen (72\%) classroom teachers observed in interviews that pre-service teacher training was too theoretical and examination oriented to impart skills and knowledge necessary for student discipline management in schools and that hey depended more on experience than training to handle student disciplinary issues. One classroom teacher put it more explicitly that "what we learnt in college were good theories which only made us intellectuals but not effective managers of classroom discipline. Sometimes we do not know how to handle disciplinary problems that arise in class because we have the knowledge but no skills". That position explicitly explains why the deputy head teachers complained of overworking by hearing most of the disciplinary cases. A classroom teacher confirmed this in the following words: "at the moment we are confused and don't know what to do with misbehaving students. Some of us involve less in student disciplinary matters and push most of such problems to the deputy head teacher". Those views imply that despite efforts made by teachers to manage discipline of students in schools, the teachers experienced marked difficulties. 
The 13 (100\%) heads of guidance and counselling observed that combining school counselling with full teaching duties was too demanding hence, the counselling aspect suffered. They explained that the manner of appointing the heads of guidance and counselling ignored merit, qualifications and implied no monetary benefits to the teacher for the extra work done. A head of guidance and counselling in a day school observed, "lessons begin at 8.00a.m and end at 4.00 p.m. No one expects you to miss a class because you were counselling a student. At 4.00 p.m all students go for games up to 5.00 p.m. Thereafter, they are in a hurry to go home and our time for school is equally up. That means no time for guidance and counselling. The ministry should think of making the exercise a full- time job". The implication here is that if MOEST is serious about the use of guidance and counseling in schools as a tool of managing student discipline then it should put up the necessary structures to support it.

Nine (69\%) deputy head teachers observed that head teachers and class teachers did not support them in handling complex disciplinary problems among students. They observed in the interviews that head teachers sometimes used guidance and counselling committees to handle disciplinary cases that plainly required punishment. That made the two committees suspicious of each other and set them at conflict hence putting student discipline in jeopardy. Such situations could easily be avoided and newly appointed deputy head teachers could adapt and perform their roles better if they were properly inducted into the needs and challenges of the new office.

Thirteen (48\%) classroom teachers observed that only head teachers, and sometimes the deputy head teachers, attended student barazas while they did not attend and the head teachers sometimes discussed them with the students. Five (23\%) classroom teachers indicated that the head teacher told the students during a baraza that they should not run errands for teachers. When the teachers realized that, they withdrew quietly from serving the students after the official working time and resorted to referring most student disciplinary cases to the head teacher or deputy head teacher. In another $5(23 \%)$ cases the classroom teachers indicated that the head teachers used the baraza to stir students against the deputy head teachers whom they accused of highhandedness. The purported complaints were later presented to the Provincial Director of Education (PDE) who demoted those deputies. From those cases, it was apparent that most head teachers did not use barazas meaningfully, transparently and maturely to enhance healthy dialogue in the school. They, instead, used them as ruses to fight strange internal battles in the school. A deputy head teacher heads the disciplinary committee and is equally in charge of discipline in the school and when he/she is transferred in any capacity there should be clear procedure for succession so that school discipline does not collapse. In that those transfers were not well planned and were responsible for the case of arson that was mentioned earlier in the disciplinary problems that faced schools. Therefore, when barazas are not used maturely then they spell doom in the management of student discipline because the principle of collective responsibility is neglected. Koech Report (Republic of Kenya, 1999) observed that heads of institutions have put several barriers between various participants such as the administration, teaching staff, parents and the students, which cause indiscipline among students and general apathy among teaching staff in schools.

Some $23(86 \%)$ class teachers observed that some parents were difficult and uncooperative. Teacher observed that parents colluded with and concealed the background information of their children facing disciplinary problems in schools and that impeded the efforts of teachers to help such children meaningfully. A case was reported in the interviews with class teachers where a parent accompanied his child to school and without waiting to hear why the student was sent home threatened to 'fix' the teachers. Given such threats, and without any concrete background information about the child, the teacher's task of managing student discipline in schools becomes even more daunting. That partly explained why teachers referred most student disciplinary problems to the deputy head teachers and guidance counselors.

An education policy that ignores the classroom teacher, who is the professional and educational practitioner and bears the fate of the policy on the ground, cannot succeed. Apparently, that was the position of such policies that were conceived without consulting with the classroom teacher. Some 20 (77\%) classroom teachers observed that they never participated in formulating disciplinary policies in their schools. Without such participation, it was difficult for them to implement the policies effectively. A classroom teacher captured it in the following words, "the rules and regulations we use here in school were drawn when the school was put up in the 1960s. Each year they are reproduced and given to new students. Some of us come to know of those rules when we appear at the disciplinary committee over a case involving a member of our class". No wonder, the 
deputy head teachers were left alone to implement the policies because they were expected to be in school always, and were blamed if the policy failed. Since management of student discipline in schools requires collective action and unity of purpose of all the teachers when the teachers do not understand the disciplinary policy well they would find it difficult to implement it. The consequence is that the desired unity of purpose is lost as each teacher acts individually and consequently the office of the deputy head teacher that is responsible for discipline in the school is overworked.

The study also established that teachers were their own enemies as they incited students against one another and against the school administration. During the interviews, 6 (45\%) deputy head teachers indicated that teachers incited students against the office. Cases were reported where teachers went to class and asked the students to march to the head teacher's office and bring pieces of chalk. In others teachers found students working out during class time and told them that the punishment was illegal since it violated their right to learn. Here, the intention of the teacher may be deduced as malicious and inciter. If they ever intended well it could be construed from the behaviour they displayed. The Despite that behaviour of teachers 11 (100\%) H/Ts strongly agreed that for any school disciplinary policy to succeed the cooperation of the teachers was important.

From the fore going, the teacher seemed to experience a number of difficulties while managing student discipline in schools. Additionally, the teacher did not appear to be adequately prepared to manage student discipline in schools effectively. That implied that the teacher seemed to require support in order to manage student discipline in a better way. The kinds of support the teacher required forms the next stage of discussion.

\subsection{Support to the Teacher}

When asked on the kinds of support the teacher required in order to manage student discipline in schools in a better way, the respondents identified the following areas:

Teachers seemed to require in-service training on guidance counseling and student discipline management to update their skills of managing student discipline in school. When asked if they required inservice training to manage student discipline, the responses were as follows:

Table 4: Teachers Require In-Service Training to Manage Student Discipline

\begin{tabular}{|c|c|c|}
\hline $\begin{array}{l}\text { Response } \\
\text { Level }\end{array}$ & $\begin{array}{l}\text { Students } \\
\mathbf{n}=780 \\
\mathrm{~F}(\%)\end{array}$ & $\begin{array}{l}\mathrm{DH} / \mathrm{Ts} \\
\mathrm{n}=13 \\
\mathrm{f}(\%)\end{array}$ \\
\hline SA & $390(50)$ & 09 (69.2) \\
\hline A & $210(27)$ & $02(15.4)$ \\
\hline $\mathrm{U}$ & $62(08)$ & \\
\hline $\mathrm{D}$ & $46(06)$ & $02(15.4)$ \\
\hline $\mathrm{SD}$ & $46(06)$ & \\
\hline
\end{tabular}

From Table 4, a total of 600 (77\%) students and 11 (84,6\%) deputy head teachers agreed that teachers required in-service training to enable them manage student discipline in a better way. From that finding it was necessary to provide all teachers with that important skill hence; it should not focus on the appointed heads of guidance and counselling only. That was necessary because the abilities of the teacher to cope with the challenges of teaching and discipline management in schools depends much on their ability to continue learning. Again, the in-service training should also focus on classroom discipline management in order to remove the feelings of inadequacy and lack of confidence among teachers. Since guidance and counseling was the new and recommended method of managing student discipline in schools, the MOEST should pursue vigorously a policy of in-service so that teachers do not feel deficient in using it. 
All the 26 (100\%) C/Ts, 13 (100\%) heads of G\&C, 13 (100\%) DH/Ts and 11 (100\%) H/Ts indicated that preservice training of teachers did not seem to prepare teachers enough for management of student discipline. When asked whether pre-service training gave them sufficient skills for managing student discipline in schools the $\mathrm{C} / \mathrm{Ts}$ and $\mathrm{DH} / \mathrm{T}$ s responded as follows:

Table 5: Teachers have Sufficient Skills for Managing Student Discipline

\begin{tabular}{lll}
\hline Response & $\mathbf{C} / \mathbf{T s}$ & $\mathbf{D H} / \mathbf{T s}$ \\
Level & $\mathbf{n}=\mathbf{2 6}$ & $\mathbf{n}=\mathbf{1 3}$ \\
& $\mathbf{f}(\%)$ & $\mathbf{f}(\%)$ \\
& & \\
\hline SA & $03(11)$ & $03(27)$ \\
A & $08(30)$ & $07(64)$ \\
U & $01(04)$ & $02(18)$ \\
D & $11(42)$ & \\
SD & $02(08)$ & $01(09)$ \\
\hline
\end{tabular}

From Table 5, 10 (71\%) DH/Ts agreed that teachers had sufficient skills for managing student discipline, 2 (18\%) were undecided while 1 (9\%) strongly disagreed. On the other hand, 11 (43\%) C/Ts agreed that teachers had sufficient skills for managing student discipline 1 (4\%) was undecided while 13 (50\%) disagreed. It appeared that $\mathrm{DH} / \mathrm{Ts}$ were more confident with their skills compared to the class teachers. During the interviews the classroom teachers more than the deputy head teachers also emphasized the need to review the teacher training curricula to include more credit hours on student discipline management and that guidance and counselling at pre-service teacher training should be made a distinct unit to make teacher-trainees master it more thoroughly. That discrepancy appeared interesting and required investigation. The researcher went further to analyze the professional qualifications of the teacher in order to find out if it could explain the discrepancy. Table 14 shows the professional qualifications of the teachers.

\section{Conclusions}

The study concluded that:

* Secondary schools in Bondo District seemed to experience disciplinary problems among students, like, other districts in Kenya;

* The teachers seemed unprepared to manage student discipline in schools effectively. They seemed to use methods that were punitive and illegal but which the students found acceptable. A combination of those school based punitive, corporate and democratic styles coupled with reliance on external resource personnel, accounted for the calmness and tranquility that prevailed in secondary schools in Bondo District.

* The disciplinary trends in the secondary schools in the district appeared to be rising. While the teacher seemed to be aware of the MOEST policy on school discipline, the methods they used to manage student discipline negated that sense of awareness. In fact it reflected a kind of protest to the MOEST policy, which the teacher was not keen to follow.

* The teacher seemed to experience many difficulties while managing student discipline hence appeared to require a lot of support. 


\section{Recommendations}

From the study findings the following recommendations were made;

1. Need to mount periodic in-service teacher training for updating skills and enrich pre service teacher training with more units on student discipline management.

2. Need to post to schools full time professional counsellors in order to relieve the office of the heavy teaching duties, which currently make it ineffective.

3. Need for parents to provide teachers with full background information about the children so that teachers can help those children better.

4. Need to base teacher promotion in schools on ability to manage student discipline and previous record of service in administrative position like class teacher.

5. Teachers need to respect the ban on corporal punishment as a disciplinary strategy and use methods that the MOEST recommends.

6. The high poverty levels in Bondo District need to be addressed urgently in order to minimize the magnitude of student disciplinary problems in secondary schools.

\section{Suggestions for Further Research}

1. The influence of learning and teaching facilities in schools on student discipline;

2. The role of the local community and the provincial administration on student discipline and

3. The role of the PTA in the management of student discipline in secondary schools.

\section{References}

Aduda, D. (2001, April 14). Corporal punishment. Daily Nation.

Bagunywa, M. A. (1980). Critical Issues in Education: A Case Study of Uganda.Kampala: East African Publishing House.

Ball, J. (1989). The National PTA's stand on corporal punishment". The Educational Digest LIV, 8, pp.23-25. Michigan: Prakken Publications.

Beauchamp, L. \& Parson, J. (1992).Teaching from Inside Out: An Introduction to What Teaching is Really About. Edmonton: Les Editions Dural Inc.

Borg, R.W., Gall, P.J. \& Gall, D.M. (1993). Applying Educational Research: A PracticalGuide. $3^{\text {rd }}$ ed. New York. Longman.

Chambers, H. J. (1983).The Achievement of Education: An Examination of Key Concepts in Educational Practice. Lanham: University Press of America.

Cheal, E. J.,Melsness, C. H. \& Reeves, W. A. (1962). EducationalAdministration: TheRole of the Teacher. Toronto: Macmillan.

Clewett, S.A. (1988). Discipline as teaching rather than punishment. In The Education Digest LIV, 2 pp.42-45. Michigan: Prakken Publications Inc.

Cohen,L \& Manion,L (1994). Research Methods in Education. London. Routledge

Daily Nation Team, (2001, June 25). Queries over caning ban. Daily Nation, p.27.

Daily Nation Editorial, (2001, July 20). Schools unrest and ban on corporal punishment.Daily Nation.

Day, A. R. (1998). How to Write and Publish a Scientific Paper. $5^{\text {th }}$ ed. Cambridge: Cambridge University Press.

Don, F. (1993). Effective classroom discipline: advice for educators NASSP Bulletin 76 (549): pp. 82-86.

Duke, L. D. (1991).Teaching: An Introduction. New York: Mc Graw HillPublishing Company.

Durojaiye, M.O.A (1976). A New Introduction to Educational Psychology. London:Evans Brothers LTD.

Eshiwani, G. (1993).The role of research in educational policy and practice in Africa with special reference to Kenya. Educational Research for Development in Africa, pp.41-46 P. M. Mutebi and M. Y. Matovu (Eds.). Dakar: UNESCO.

Fraenkel, R.J. \& Wallen, E.N. (1993). How to Design and Evaluate Research inEducation. $2^{\text {nd }}$ ed. NewYork. Mc Graw-Hill Inc

Gall, M.D., Borg, R.W. \& Gall, P.J. (1996). Educational Research, An Introduction. $6^{\text {th }}$ ed. New York. Longman Publishers.

Gikandi, B. \& Ngamau, M. (2005, March 24). Roll of barbed wire: Tool that fights truancy. The Standard: School and Career, p.7.

Glasser, W.M.D. (1990). The Quality School. Managing Students WithoutCoercion. New York: Harper and Row Publishers Grinnel, M. R. J.R. (1993). Social Work Research and Evaluation. $4^{\text {th }}$ ed. Illinois: F.E Peacock Publishers, Inc 
Griffin, G. (1994). School Mastery. Straight Talk About Boarding School Management in Kenya. Nairobi: Lectern Publications LTD.

Hendrikz, E. (1986). Introduction to Educational Psychology. London: Macmillan Publishers.

Hawes, H. (1979).The curriculum of teacher education. In Teacher Education in Developing Countries: Prospects for the Eighties. Series of Lectures, Responses and Seminars to Mark the 50th Anniversary of the Department of Education in Developing Countries. University of London Institute of Education.

Hyman, A. I. (1988).Corporal punishment. Encyclopaedia of SchoolAdministration and Supervision, pp.79-80 R. A. Gorton, G. T.Schneider \& J. C. Fisher, (Eds.) New York: Oryx Press.

Indoshi, F.C. (1999). "An assessment of in-service education and training needs of primary school agriculture teachers in Kenya: A case study of Vihiga district". Unpublished doctoral dissertation, Maseno University.

(2003).Teachers' experiences of the probation period of teaching in Kenya: implications for teacher induction policies and programmes". Journal of In-service Education: an international journal of professional development.

L. Malcolm and G. Bob (Eds.). 29, 3, pp. 473-488. Wallingford: Triangle Journal Limited.

Isaacs, D. (1984).Character Building: A Guide for Parents and Teachers. Nairobi: Four Courts Press.

John, W. (1981).Discipline and Moral Education: A Survey of Public Opinion and Understanding. Windsor: NFER-Nelson Publishing Company LTD.

Kamuyu, C. (2001, June 30).Discipline: Try guidance not the cane. The Standard, p.12.

Keeshan, B. (1989).Banning corporal punishment in the classroom. TheEducational Digest, LIV, 8 pp.19-22. Michigan: Prakken Publications.

Kenyatta, J. (1978).Facing Mount Kenya: The Traditional Life of the Gikuyu.Nairobi: Heinemann.

Kimotho, K. (2001, April 14). Heads' new challenge in students' discipline. The Standard, pp.15-17.

Kimotho, K. (2001, June 25). Unfinished business in head teachers' meeting. The Standard, p.6.

Kimutai, V. (2005, March 24). Why children can be kicked out of school. The Standard: School and Career, p.15.

Ki-Zerbo, J. (1990).Educate or Perish: Africa's Impasse and Prospects. Dakar: UNESCO-UNICEF Publication.

Lumiti, D. \& Ongeri, B. (2005, March 24). Measure is extreme but necessary. The Standard: School and Career, p.5.

MacDonald, M. I. (1997). Violence in schools: Multiple realities. Alberta Journal ofEducational Research XLIII, 2/3, pp. 142-155. Edmonton: Ajer.

Madden, L. (1988).Teacher communication and student self-esteem. TheEducational Digest LIV,1 pp.50-52. Michigan: Prakken Publications.

Makabila, S (2005, March 24). Policy changes from expulsion to exclusion. The Standard: School and Career, p.6.

Makinde, O. (1984). Fundamentals of Guidance and Counselling. LondonMacmillan Publishers LTD.

Mbiti, M. D. (1974).Foundations of School Administration. Nairobi: OxfordUniversity Press.

Migiro, N. N. (1996). "An investigation into the state of guidance and counselling in secondary schools of Borabu division in Nyamira district". Unpublished research project for post-graduate diploma in education, Kenyatta University.

Ministry of Education. (1987). A Manual for Heads of Secondary Schools in Kenya. Nairobi: Government Printers.

Miriam, H.,Knight, J.,Lingard, R. \& Taylor, S. (1988). Understanding Schooling:An Introductory Sociology of Australian Education. London: Routledge.

Muli, A. (2005, April 21).Games that bring students and teachers together. The Standard: School and Career, p.15.

Muniu, M. (2005, March 24). Burden of indiscipline. The Standard: School and Career, p.5.

Muya, W. \& Mwanzia, M. (2005, March 24). American students love to be suspendedfrom school. The Standard: School and Career, p.6.

Mwiria, K. (1995).Educational research and policy formulation: The Kenyaexperience. Issues in Educational Research in Africa, pp. 27-42, K. Mwiria and S. P. Wamahiu (Eds.). Nairobi: East African Educational Publishers

Ndamburi, S. N. (1995)."An Investigation into the problem of indiscipline insecondary schools: Case study of Karumandi and Mugumo secondary schools in Kirinyaga district". Unpublished post-graduate diploma in education research project, Kenyatta University.

Ndiritu, J. K. (1996)."An investigation into the provision of guidance and counselling services in Kenyan secondary schools: Case study of Ndaragua division in Nyandarua district". Unpublished post-graduate diploma education research project, Kenyatta University.

Ngóngá, B. G. (2002). "An assessment of English language teacher educationin the light of classroom needs: A case study of Maseno University". Unpublished doctoral dissertation, Maseno University.

Obanya, P. (1993).Levels of educational research with possible implications for policy and practice. Educational Reseach for Development in Africa, pp.9-16 P. M. Mutebi and M. Y. Matovu (Eds.). Dakar: UNESCO.

Obiero, C.A. (2005,March 24). Lack of democracy cause of problems in our schools. The Standard: School and Career, p.15. 
Ocitti, J.P. (1973).African Indigenous Education as Practised by the Acholi ofUganda. Nairobi: Kenya Literature Bureau.

Odinga, O. (1967).Not Yet Uhuru: An Autobiography.Nairobi: HeinmannPublishers.

Oduor, A. (2005, March 31).Principal aims at the top. The Standard: School and Career, p.14.

Oduor,A. \& Kimutai, V. (2005, March 24). School principals' crude way to boost exam results. The Standard: School and Career, p.7.

Oirere, S. (2005, March 17).On whose interests are head teachers transferred? The Standard: school and Career, p. 8.

Okumbe, J.A. (1998). Educational Management Theory and Practice. Nairobi:Nairobi University Press.

Olembo, J. O. \& Camero, J. (1986).Practical Primary School Administration for Students, Teachers and Heads. London: Edward Arnold Publishers.

Olembo, J.O., Wanga, P.E., \& Karagu, N.M. (1992). Management in Education.Nairobi: ERAP.

Oliva, F. P. (1989).Supervision for Today's Schools. $3^{\text {rd }}$ ed. New York: Longman.

Otieno, O. (2005, March 24).Ex-student leader remembers. The Standard: School and Career, p.6.

Papalia, E. D. \& Olds, W. (1990). A Child's World: Infancy through Adolescent. $5^{\text {th }}$ ed. New York: Mc Graw Hill Publishing Co.

Pink, T. W. (1988).Student responsibility. Encyclopaedia of SchoolAdministration and Supervision, pp.255-256, R. A. Gorton, G. T. Schneider and J. C. Fisher, Eds. New York: Oryx Press.

Raju, M. B. (1973).Education in Kenya: Problems and Perspectives in Educational Planning and Administration. London: Heinmann Educational Publishers.

Republic of Kenya (1972). Laws of Kenya: The Children and Young Persons Act.Nairobi: Government Printers. (1976).Report of the National Committee on EducationalObjectives and Policies, (Gachathi Report). Nairobi: Government Printers. (1980).Education Act Cap. 211,1980. Nairobi: Government Printers (1981).Report of the Presidential Working Party on the SecondUniversity in Kenya. Nairobi: Government Printers. (1987).Education in Kenya: Information Handbook. Nairobi: Jomo Kenyatta Foundation. (1988).Report of the Commission of Inquiry into the Educationand Manpower Training for the Next Decade and Beyond. Sessional Paper No.6 (Kamunge Report). Nairobi: Government Printer.

(1998).Master Plan on Education and Manpower Training 1997-2010.Nairobi: Jomo Kenyatta Foundation.

(1999). Report of the Commission of Inquiry into the Education System of Kenya, (Koech Report). Nairobi: Government Printers.

(2001,March 30).Kenya Gazette Supplement No.25.Nairobi: Government Printers.

(2001).Report of the Task Force on Student Discipline and Unrest in Secondary Schools. Nairobi: Jomo Kenyatta Foundation.

(2002).Bondo District Development Plan 2002-2008. Nairobi:Government Printers.

(2002)"TSC Scheme of Service for Graduate Teachers, Revised Graduate Scheme (On-line) file://A:\ Revised Graduate Scheme htm.

Sadker, M. P. \& Sadker, D. M. (1991). Teachers, Schools and Society, $2^{\text {nd }}$ ed.New York: Mc Graw Hill Inc.

Satles, B. (1989).Parental involvement in student learning. Educational Digest LIV, 8 pp.37-39. Michigan: Prakken Publications.

Sifuna, N.D. (1980).Short Essays on Education in Kenya. Nairobi: Kenya Literature Bureau.

Tuiyot, A. (2001, June 21).Teachers tipped on ways to reduce students' unrest.The Standard p.9.

Ukeje, B.O., Akabogu, G.C. \& Ndu, A. (1992). Educational Administration. Enugu:Fourth Dimension Publishing Co. LTD.

UNESCO. (1991).Strengthening Educational Research in Developing Countries. Paris: UNESCO.

Waigwa, J. M. (1996). "An investigation into the causes of indiscipline: The case of Gathanji secondary school". Unpublished post- graduate diploma in education research project, Kenyatta University.

Waihenya, K. (2001, June 11). Teachers question new rule on caning. DailyNation, p.17.

Wangeri, T. (1986)."A special study of discipline problems affecting secondary schools in Thika". Unpublished master's thesis, Kenyatta University.

Wheldall, K. \& Merrett, F. (1984).Positive Teaching: The Behavioural Approach. London: George Allen and Urwin.

World Bank (1980). Education Sector Policy Paper. Washington DC: World Bank. 
